\title{
Genetic progress in winter wheat quality and quantity parameters
}

\author{
Ágnes Fekete - Péter Pepó \\ University of Debrecen, Institute of Crop Science, Faculty of Agricultural and Food Sciences and Environmental Management, 4032, \\ Debrecen, Hungary, Böszörményi Str., 138 \\ fekete.agnes.91@gmail.com
}

\section{SUMMARY}

Wheat production is significant branch of Hungarian crop production (with about 1 million hectares of sowing area). Weather anomalies resulted by climate change have increased the importance of biological basis in wheat production. Yield quality and quantity parameters of three wheat genotypes sown on chernozem soil type after maize pre-crop were studied in a long-term field experiment. Yield amount of the studied genotypes varied between 2894 and $8074 \mathrm{~kg} \mathrm{ha}^{-1}$ in 2017 and between 5795 and $9547 \mathrm{~kg} \mathrm{ha}^{-1}$ in 2018 depending on the applied treatments. Based on our results it can be stated that in both studied crop years the highest yield increment was realized by the application of the nutrient supply level of $N_{30}+P K$. As the result of the application of the optimum mineral fertilizer level-in contrast to the control-resulted in significant yield increment in both crop years. The results of the long-term field experiment prove that water utilization of the studied wheat varieties / hybrids was improved by the application of the optimal nutrient supply. Furthermore, the water utilization of the latest genotypes was more favorable by both the control and the optimum nutrient supply level treatments. Analyzing the quality parameters of winter wheat using the NIR method it has been stated that the quality results of the well-known genotype (GK Öthalom) were better than those of the new genotypes. A negative correlation between winter wheat quality and quantity parameters has also been confirmed. As the result of the mineral fertilizer application protein and gluten content of winter wheat increased to a significant extent.

Keywords: wheat, variety, hybrid, pre-crops fertilizer responses, WUE

\section{INTRODUCTION}

Winter wheat production has a determining role not only in Hungary but in the European Union market as well. According to the statistics of FAOSTAT, winter wheat was produced in 2107 in the European Union on an area of 26 million hectares with an average yield of 5.7 tons per hectare, while in Hungary 5.37 million tons of winter wheat was harvested on the area of 1 million hectares with an average yield of 5.2 tons per hectare $(\mathrm{KSH})$. Only winter wheat with excellent quality parameters is suited for the European market. Yield potential and grain yield quality is basically determined by the genotype and the environment, similarly to the interaction between them (Rozbicki et al., 2015). The effect of the crop year is the most determining among the environmental factors: weather conditions affect the yield quality at a rate of about 22\% (Pepó et al., 2018). Winter wheat shows a sensitive reaction towards dry, drought periods especially during the growth stage (Chen et al., 2015; Ravier et al., 2017). In addition, nutrient supply is the other agrotechnical factor that affects the yield amount and quality parameters (protein and gluten content) of winter wheat (by 20\%). According to Samborski (2009) especially the nitrogen supply that meets the demand of the crop has the highest effect, which has both direct and indirect influence on the effect of other agrotechnical factors (pre-crop, crop rotation, soil cultivation, plant protection). In previous studies, the application of high nitrogen mineral fertilizer dosages increased protein and wet gluten contents as well (Szániel et al., 1975; Alda et al., 2010). According to the studies of Zecevi et al. (2010) the Zeleny sedimentation value and raw gluten content increased significantly in parallel to the increasing nitrogen dosage applied. Pepó et al. (2014) stated that the basic precondition of high-quality winter wheat production is the genetic basis with adequate genetic parameters. A wide range of quality parameters are characteristic of the different winter wheat varieties and hybrids. The selection of the genotype, including variety is of extraordinary and determining significance. Basic determining factors are potential yield, yield stability, yield safety and quality. Recently and in the upcoming years genotypes that show high baking quality and keep up their productivity even among extreme crop years or production sites is becoming more and more important. They provide more favorable marketing possibilities for both producers and vendors. The latest breeding programs' primary aim is to produce genotypes that are able to produce high yields with maintaining the level of the adequate quality parameters as well (Fang et al., 2017). Hungarian wheat production had a long and successful development in the past decades. The range of available varieties in the Hungarian market has been significantly extended in the past years. Currently the number of varieties listed on the national variety list is over 100 . However, producers choose the one to sow only between some well-known varieties (Pepó et al., 2019).

\section{MATERIALS AND METHODS}

\section{Experimental setup parameters}

Pre-crop of the experiment was sweet corn. In both crop years two early ripening wheat varieties with excellent milling quality parameters: GK Öthalom, and Mv Ispán, just as a late ripening hybrid with extraordinary vitality and high stability named Hyland were studied in the experiment. Each of them was accepted to the national variety list in different years: GK Öthalom was listed in 1985, the hybrid Hyland in 
2009 and Mv Ispán was registered in 2015 to the Hungarian national Variety List.

\section{Location and soil characteristics of the experimental site}

The University of Debrecen, Agricultural Research Institute and Educational Farm Látókép research Station is located on the loess plateau of the region Hajdúság, along the main traffic road nr. 33, 15 kilometers far from Debrecen. The experimental field soil level is flat, regarding its genetic properties it can be classified as a calcareous chernozem soil.

\section{Weather conditions of the experimental crop year}

Generative and vegetative development of winter wheat was basically determined by the amount and the distribution of the precipitation. Wet weather conditions during the end of summer and in the autumn period of the crop-year 2016/2017 were favourable for the development of wheat. Winter months were rather cold. The progressive warming during the early spring season had a favourable effect as well. The precipitation that fell during the flowering period affected the fertilization and grain development positively as well. Warm weather in June accelerated the ripening of the populations. Weather conditions of the crop-year 2017/2018 was considered as unfavourable. Mild weather conditions during the autumn period and the progressively cooling wet season afterwards affected the emergence and early development of plants positively. February and March were colder that the average which affected wheat development negatively. Warm weather during April and May affected the vegetative development of wheat negatively as well, the development stages were significantly shorter. Ripening of the studied populations was detected $1.5-2$ weeks earlier than the average.

\section{RESULTS AND DISCUSSION}

As a result of breeding the assortment of varieties has been significantly extended in Hungary. Furthermore, beside varieties new hybrids appeared and were sown on even larger areas. Basic aim of breeding is the have new genotypes with higher yield amount, better quality parameters and better agronomic parameters. Beside the evaluation of the nutrientreaction of the studied varieties/hybrids and the study of food quality parameters our complex long-term filed experiment enabled the study of the genetic development of different winter wheat varieties as well.

Table 1

The effect of mineral fertilization on the yield amount of winter wheat genotypes $\left(\mathrm{kg} \mathrm{ha}^{-1}\right)$ (Debrecen, 2017-2018)

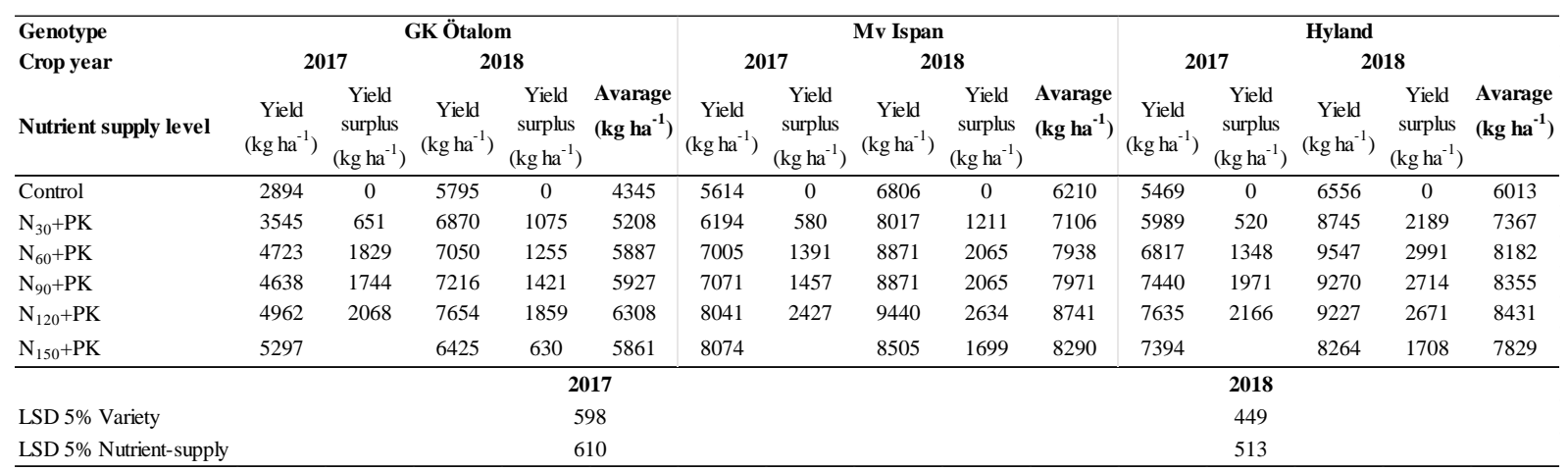

Well-known (GK Öthalom) and new (Mv Ispán) winter wheat varieties and a hybrid (Hyland) were studied in the counteractive crop-years (2017 and 2018), that enabled us - beside the determination of their reaction towards nutrient supply - to analyse their adaptivity as well. Yield amount of the studied genotypes varied between 2894 and $8074 \mathrm{~kg} \mathrm{ha}^{-1}$ in 2107 and between 5795 and $9547 \mathrm{~kg} \mathrm{ha}^{-1}$ in 2018 depending on the applied nutrient supply level (Table 1). As a result of the two counteractive crop-years the main difference between the yield results was observed in the yield of the control treatments: in 2017 the measured yield amounts of the studied genotypes ranged between 2894 and $5614 \mathrm{~kg} \mathrm{ha}^{-1}$, while in 2018 between 5795 and $6806 \mathrm{~kg} \mathrm{ha}^{-1}$. The effect of different agro-ecological factors on the yield could be significantly decreased in the studied different cropyear by applying optimum nutrient supply. Maximum yield of the studied genotypes varied between 5297 and $8074 \mathrm{~kg} \mathrm{ha}^{-1}$ in 2017, while between 7654 and 9547 $\mathrm{kg} \mathrm{ha}^{-1}$ in 2018. In contrast to the control nutrient supply level the yield increment resulted by the application of the optimum nutrient supply level was significant in both studied crop-years. Yield surplus resulted by the nutrient supply ranged between 2166 and $2460 \mathrm{~kg} \mathrm{ha}^{-1}$ in 2017, while in 2018 between 1859 and $2991 \mathrm{~kg} \mathrm{ha}^{-1}$ in case of the studied genotypes. Depending on the studied genotype in 2017 the supply level of $\mathrm{N}_{120^{-} 150}+\mathrm{PK}$, while in $2018 \mathrm{~N}_{60-120}+\mathrm{PK}$ was considered as the optimum mineral fertilizer dosage.

Evaluating both studied crop-years of the long-term field experiment it has been stated that in contrast to the well-known genotype (GK Öthalom) both the novel variety (Mv Ispán) and the hybrid (Hyland) showed more favourable absolute and relative yield amount parameters (Table 1). The results of the studied two 
years prove that the novel genotypes have better nutrient utilisation ability, their yield amounts were higher in the control treatment. The average yield amount of the well-known genotype in the control treatment was $4345 \mathrm{~kg} \mathrm{ha}^{-1}$, while that of the new genotypes was $6210 \mathrm{~kg} \mathrm{ha}^{-1}$ (Mv Ispán) and 6013 $\mathrm{kg} \mathrm{ha}^{-1}$ (Hyland) respectively. Genetic progression was realized both, in yield potential and its realized value (maximum yield amount). Maximum yield of GK Öthalom was $6308 \mathrm{~kg} \mathrm{ha}^{-1}$, while the novel genotypes produced $8741 \mathrm{~kg} \mathrm{ha}^{-1}$ (Mv Ispán) and $8431 \mathrm{~kg} \mathrm{ha}^{-1}$ (Hyland). Furthermore our experimental result proved that under favourable soil and almost optimal agrotechnologic conditions there was no significant difference between the maximum yield amount of the novel variety and the hybrid. Advantages of the heterosis effect of the hybrid could possibly be revealed under less favourable production conditions.

In the study of winter wheat genotypes with different breeding time efficiency parameters showing the nutrient and water utilisation of the genotypes were evaluated as well. Analysing the yield surplus amounts resulted by $1 \mathrm{~kg}$ NPK mineral fertilizer active substance it can be stated that novel genotypes show higher results (Table 2). Relative nutrient utilisation values of GK Öthalom in 2017 ranged between -0.4 and 8.2, in 2018 between -3.1 and $13.6 \mathrm{~kg} / 1 \mathrm{~kg}$ NPK. In case of Mv Ispán these values varied between 0.1 and 7.3 (2017) and between -2.4 and $5.3 \mathrm{~kg} / 1 \mathrm{~kg}$ NPK. For the hybrid Hyland relative nutrient utilisation vales ranged between -0.6 and 6.6 (in 2017) and between -2.4 and $27.7 \mathrm{~kg} / 1 \mathrm{~kg}$ NPK.

Table 2

Yield increment amount resulted by $1 \mathrm{~kg}$ NPK fertilizer active substance in contrast to the control treatment (Debrecen, 2017-2018)

\begin{tabular}{|c|c|c|c|c|c|c|c|c|c|c|}
\hline \multirow{2}{*}{$\begin{array}{l}\text { Nutrient } \\
\text { supply level } \\
\text { Crop year }\end{array}$} & \multicolumn{2}{|c|}{$\mathbf{N}_{30}+\mathrm{PK}$} & \multicolumn{2}{|c|}{$\mathrm{N}_{60}+\mathrm{PK}$} & \multicolumn{2}{|c|}{$\mathbf{N}_{90}+\mathbf{P K}$} & \multicolumn{2}{|c|}{$\mathrm{N}_{120}+\mathrm{PK}$} & \multicolumn{2}{|c|}{$\mathrm{N}_{150}+\mathrm{PK}$} \\
\hline & 2017 & 2018 & 2017 & 2018 & 2017 & 2018 & 2017 & 2018 & 2017 & 2018 \\
\hline GK Öthalom & 8.2 & 13.6 & 7.5 & 1.1 & -0.4 & 0.7 & 1.0 & 1.4 & 0.8 & -3.1 \\
\hline MV Ispán & 7.3 & 15.3 & 5.1 & 5.4 & 0.3 & 0.0 & 3.1 & 1.8 & 0.1 & -2.4 \\
\hline Hyland & 6.6 & 27.7 & 5.2 & 5.1 & 2.6 & -1.2 & 0.6 & -0.1 & -0.6 & -2.4 \\
\hline
\end{tabular}

Water use efficiency of winter wheat genotypes under different nutrient supply levels (WUE= Water USE Efficiency =grain yield amount per each mm amount of precipitation during the vegetation period) (Debrecen, 2017-2018)

\begin{tabular}{lccccc}
\hline & & & & \multicolumn{2}{c}{$\mathbf{2 0 1 8}$} \\
& GK Öthalom & MV Ispan & Hyland & GK Öthalom & MV Ispan \\
\hline Control & 5.6 & 10.9 & 10.6 & 11.5 & 13.5 \\
NPK Optimum & 10.3 & 15.7 & 14.8 & 15.2 & 13.0 \\
\hline
\end{tabular}

Our results of the long-term field experiment proved that water use efficiency (WUE = grain yield amount per each $\mathrm{mm}$ precipitation during the vegetation period) of winter wheat varieties/hybrid was improved by the application of the optimum nutrient supply level. Furthermore, the water utilisation of the novel genotypes was better in case of both lacking (control) and optimum nutrient supply level treatments. In the crop-years 2017 and 2018 WU values of the variety GK Öthalom varied between 5.6 and 11.5 $\mathrm{kg} \mathrm{mm}^{-1}$ in the control treatment, while in the optimum nutrient supply level treatment between 10.3 and 15.2 $\mathrm{kg} \mathrm{mm}^{-1}$ (Table 3). On the contrary the novel variety Mv Ispán showed water use efficiency values between 10.9 and $13.5 \mathrm{~kg} \mathrm{~mm}^{-1}$ in the control nutrient supply level treatment and between 15.7 and $18.8 \mathrm{~kg} \mathrm{~mm}^{-1}$ in the optimum nutrient supply level treatment. The novel bred hybrid Hyland's water use efficiency values ranged between 10.6 and $13.0 \mathrm{~kg} \mathrm{~mm}^{-1}$, and between 14.8 and $19.0 \mathrm{~kg} \mathrm{~mm}^{-1}$ in the control and the $\mathrm{N}_{\text {opt }}+\mathrm{PK}$ nutrient supply level treatments.
Even though winter wheat quality has less importance lately we consider the study of the quality parameters beside quantity as basic for the complex evaluation of the genotypes. In the crop-years 2017 and 2018 the two main quality parameters, i.e. protein and wet gluten content of the studied genotypes were determined by the NIR method in case of some selected nutrient supply levels (control, $\mathrm{N}_{90}+\mathrm{PK}, \mathrm{N}_{150}+\mathrm{PK}$ ). Our results confirm that the well-known genotype (GK Öthalom) showed better quality parameters than the novel genotypes (Mv Ispán, Hyland). Our results in the long-term field experiment prove that there is a negative correlation between quality and quantity parameters of (Table 4). Raw protein content of GK Öthalom varied between 10.5 and $12.4 \%$ in 2017, while that of the novel genotypes were lower (Mv Ispán 10.0-11.6\%, Hyland 9.7-11.6\%). Similar tendency was observed regarding the results in 2018 (GK Öthalom 10.2-14.0\%, Mv Ispán 10.8-13.6\%, Hyland $10.2-12.5 \%$ ). Higher nutrient supply treatments increased protein content to a significant extent in case of all studied genotypes in both studied crop-years. 
The effect of the genotype and nutrient supply on the raw protein content of winter wheat (\%) (Debrecen, 2017-2018)

\begin{tabular}{|c|c|c|c|c|c|c|c|c|}
\hline \multicolumn{9}{|c|}{ Protein content $(\%)$} \\
\hline & \multicolumn{4}{|c|}{2017} & \multicolumn{4}{|c|}{2018} \\
\hline & Control & $\mathbf{N}_{60}+\mathbf{P K}$ & $\mathrm{N}_{120}+\mathrm{PK}$ & Average & Control & $\mathrm{N}_{60}+\mathrm{PK}$ & $\mathrm{N}_{120}+\mathrm{PK}$ & Average \\
\hline GK Öthalom & 10.5 & 11.8 & 12.4 & 11.6 & 10.2 & 12.6 & 14.0 & 12.2 \\
\hline MV Ispan & 10 & 10.5 & 11.6 & 10.7 & 10.8 & 13.0 & 13.6 & 12.4 \\
\hline Hyland & 9.7 & 10.8 & 11.6 & 10.7 & 10.2 & 12.0 & 12.5 & 11.6 \\
\hline Average & 10.1 & 11.0 & 11.9 & - & 10.4 & 12.5 & 13.4 & - \\
\hline LSD 5\% Variety & \multicolumn{4}{|c|}{0.52} & \multicolumn{4}{|c|}{0.39} \\
\hline $\begin{array}{l}\text { LSD 5\% } \\
\text { Nutrient-supply }\end{array}$ & \multicolumn{4}{|c|}{0.35} & \multicolumn{4}{|c|}{0.72} \\
\hline
\end{tabular}

The effect of the genotype and nutrient supply on the wet gluten content of winter wheat (\%) (Debrecen, 2017-2018)

\begin{tabular}{|c|c|c|c|c|c|c|c|c|}
\hline & \multicolumn{8}{|c|}{ Wet gluten content $(\%)$} \\
\hline & \multicolumn{4}{|c|}{2017} & \multicolumn{4}{|c|}{2018} \\
\hline & Control & $\mathrm{N}_{60}+\mathrm{PK}$ & $\mathrm{N}_{120}+\mathrm{PK}$ & Average & Control & $\mathrm{N}_{60}+\mathrm{PK}$ & $\mathrm{N}_{120}+\mathrm{PK}$ & Average \\
\hline GK Öthalom & 21.4 & 25.6 & 27.8 & 24.9 & 19.0 & 26.5 & 30.7 & 25.4 \\
\hline MV Ispan & 19.7 & 21.5 & 24.9 & 22.0 & 21.0 & 26.9 & 28.3 & 25.4 \\
\hline Hyland & 18.6 & 22.3 & 24.6 & 21.8 & 19.2 & 24.7 & 25.7 & 23.2 \\
\hline Average & 19.9 & 23.1 & 25.8 & - & 19.7 & 26.0 & 28.2 & - \\
\hline LSD 5\% Variety & \multicolumn{4}{|c|}{1.71} & \multicolumn{4}{|c|}{1.05} \\
\hline LSD 5\% Nutrient-supply & \multicolumn{4}{|c|}{0.98} & \multicolumn{4}{|c|}{1.97} \\
\hline
\end{tabular}

One of the most important bakery parameter of winter wheat is wet gluten content. As the result of mineral fertilization wet gluten content of the studied varieties/hybrid increased to a significant extent in both 2017 and 2018. In contract to the novel genotypes the well-known genotype showed higher wet gluten content in both crop-years (Table 5). Wet gluten content of the well-known GK Öthalom varied between 21.4 and $27.8 \%$ in 2017, while in 2018 between 19.0 and $30.7 \%$. In contrast to these lower values were measured for the novel genotypes in both studied cropyears in case of all nutrient supply levels: the variety Mv Ispán produced 19.7-24.9\% wet gluten content in 2017, while in 2018 between 21.0 and $28.3 \%$. The hybrid Hyland's wet gluten content results were: 18.6$24.6 \%$ in 2017 and $19.2-25.7 \%$ in 2018). Wet gluten content of the hybrid Hyland was slightly lower than that of the variety Mv Ispán in both studied crop-years; however, this difference was not significant.

\section{CONCLUSIONS}

Evaluating our experimental results, it can be stated that the yield of the studied genotypes varied between 2894 and $8074 \mathrm{~kg} \mathrm{ha}^{-1}$ in 2017, while in 2018 between 5795 and $9547 \mathrm{~kg} \mathrm{ha}^{-1}$ depending on the applied nutrient supply level. In contrast to the well-known genotype (GK Öthalom) both the novel variety (Mv Ispán) and the hybrid (Hyland) produced more favourable absolute and relative yield quantity parameters, i.e. their yield in the control treatment was higher. In case of the optimum nutrient supply level the maximum yield ranged between 5297 and $8074 \mathrm{~kg}$ ha ${ }^{1}$ in 2017, while in 2018 between 7654 and 9547 $\mathrm{kg} \mathrm{ha}{ }^{-1}$. In both crop-years significant yield increment was measured as the effect of the application of the optimal nutrient supply level in compared to the control treatment. The studied genotypes produced 2166-2460 $\mathrm{kg} \mathrm{ha}^{-1}$ yield surplus in 2017, while in 2018 1859-2991 $\mathrm{kg} \mathrm{ha}^{-1}$ as a result of the mineral fertilizer application. Depending on the genotype in 2017 the nutrient supply level $\mathrm{N}_{120-150}+\mathrm{PK}$ was considered as the optimum level, while in 2018 it was rather the $\mathrm{N}_{60^{-} 120}+\mathrm{PK}$. According to our results the novel genotypes (Mv Ispán, Hyland) show more favourable yield surplus per each kg NPK mineral fertilizer active substance than the well-known variety (GK Öthalom). Relative nutrient utilisation values of GK Öthalom varied between -0.4 and 8.2 in the crop-year of 2017, while in 2018 between -3.1 and $13.6 \mathrm{~kg} / 1 \mathrm{~kg}$ NPK. In case of Mv Ispán these values ranged between 0.1 and 7.3 (2017) and between -2.4 and $15.3 \mathrm{~kg} / 1 \mathrm{~kg}$ NPK (2018), while for Hyland the respective ranges were -0.6-6.6 (2017) and -2.4-27.7 (2018) kg/1 kg NPK. Our results of the long-term field experiment proved that water use efficiency of winter wheat varieties/hybrid was improved by the application of the optimum nutrient supply level. Furthermore, the water utilisation of the novel genotypes was better in case of both lacking (control) and optimum nutrient supply level treatments. In the crop-years 2017 and 
2018 WU values of the variety GK Öthalom varied between 5.6 and $11.5 \mathrm{~kg} \mathrm{~mm}^{-1}$ in the control treatment, while in the optimum nutrient supply level treatment between 10.3 and $15.2 \mathrm{~kg} \mathrm{~mm}^{-1}$. On the contrary the novel variety $\mathrm{Mv}$ Ispán showed water use efficiency values between 10.9 and $13.5 \mathrm{~kg} \mathrm{~mm}^{-1}$ in the control nutrient supply level treatment and between 15.7 and $18.8 \mathrm{~kg} \mathrm{~mm}^{-1}$ in the optimum nutrient supply level treatment. The novel bred hybrid Hyland's water use efficiency values ranged between 10.6 and 13.0 $\mathrm{kg} \mathrm{mm}^{-1}$, and between 14.8 and $19.0 \mathrm{~kg} \mathrm{~mm}^{-1}$ in the control and the $\mathrm{N}_{\text {opt }}+\mathrm{PK}$ nutrient supply level treatments. All these experimental results confirm the statement of Pepó (2010) that different winter wheat genotypes show significant differences in their natural nutrient utilisation ability, reaction towards nutrient supply, fertilizer utilisation ability and in their optimum fertilizer dosage. According to that it is recommended to apply a genotype-specific nutrient supply technology in winter wheat production.

According to Hegedüs (2002), nutrient supply is a determining agronomical treatment in winter wheat quality. Analysing the winter wheat quality parameters with the NIR method in our experimental work it has been stated that the well-known genotype (GK Öthalom) produced better quality parameters in contracts to the novel genotypes. Negative correlation has been stated between the quantity and quality parameters of the studied winter wheat genotypes. Raw protein content of GK Öthalom varied between 10.5 and $12.4 \%$ in 2017 , while the results of the novel genotypes were lower that these (Mv Ispán 10.0 $11.6 \%$, Hyland 9.7-11.6\%). Similar results were measured in the crop-years 2018: (GK Öthalom 10.214.0\%, Mv Ispán 10.8-13.6\%, Hyland 10.2-12.5\%). Raw protein content of the studied genotypes was increased by the application of higher mineral fertilizer dosages in both studied crop-years.

Beside raw protein, gluten content was also analysed for the studied genotypes. Confirming the statements of Pollhamerné (1971) it has been stated that - similar to the protein content - wet gluten content was increased significantly by the application of higher mineral fertilizer dosages in case of all three studied winter wheat genotypes. In case of this parameter the well-known variety produced higher gluten content values in both studied crop-years. Wet gluten content of the variety GK Öthalom varied between 21.4 and $27.8 \%$ in 2017 while between 19.0 and $30.7 \%$ in 2018 . In contrast to that lower values were measured for the novel genotypes in case of all studied nutrient supply levels in both crop-years. Wet gluten content of the variety Mv Ispán varied between 19.7 and 24.9\% in 2017 and between 21.0 and $28.3 \%$ in 2018 , while these values ranged between 18.6 and $24.6 \%$ in 2017 for the hybrid Hyland and between 19.2 and $25.7 \%$ in 2018. Wet gluten content of the hybrid Hyland was lower than those of the studied varieties in both studied crop-years.

\section{ACKNOWLEDGEMENTS}

The work/publication is supported by the EFOP3.6.3-VEKOP-16-2017-00008 project. The project is co-financed by the European Union and the European Social Fund.

\section{REFERENCES}

Alda, L.-Alda, M.L.-Baluta, D.S.-Sirbulescu, C.-Gogoasa, I. (2010): Wet gluten analysis depending on cultivar, fertilization, herbicide application and climate conditions, in winter wheat. Journal of Horticulture, Forestry and Biotechnology 14.2. 23-26.

Fang, Y.-Du, Y.-Wang, J.-Wu, A.-Qiao, S.-Xu, B.-Zhang, S.Siddique, K.H.M.-Cjen, Y. (2017): Moderate drought stress affected root growth and grain yield in old, cultivars of winter wheat. Original Research. 8. 1-12.

Hegedűs, Z.-Szentpétery, Zs.-Kassai, M.-Jolánkai, M. (2002): Protein and wet gluten contents in winter wheat grain samples. Acta Agronomica Hungarica. 50. 383-387.

Pepó, P.-Ábrahám, É.-Csajbók, J.-Dóka, L.-Kutasy, E.- Sárvári, M.-Szabó, A. (2018): Integrált növénytermesztés. 3-24.

Pepó, P.-Bódi, Z.-Kovács, A.-Kovácsné, O.H. (2014) Agrobiotechnológia. Egyetemi jegyzet. Debreceni Egyetemi Kiadó. 45-47.

Pepó, P. (2010): Agronomical study of the Hungarian wheat production. Crop production. 59. 2. 86-99.

Pepó, P. (2019): Integrált növénytermesztés 2. Alapnövények. 2019. Mezőgazda Lap és Könyvikiadó. Budapest. 23-33.

Pollhamer, E.-né (1971): Búzatermesztési kísérletek 1960-1970. Akadémiai Kiadó, Budapest.
Ravier, C.-Meynard, J.M.-Cohan, J.P.-Gate, P.-Jeuffroy, M.H. (2017): Early nitrogen deficiencies favor high yield, grain protein content and $\mathrm{N}$ use efficiency in wheat. European Journal of Agronomy. 89.16-24.

Rozbiczki, J.-Ceglinska, A.-Gozdowski, D.-Jakubczak, M.-CacakPietrzak, G.-Madry, W.-Golba, J.-Piechocinski, M.Sobczynski, G.-Studnicki, M.-Drzazga, T. (2015): Influence of the cultivar, environment and management on he grain yield and bred-making quality in winter wheat. Journal of Cereal Science. 61. 126-132.

Samborski, S.M.-Tremblay, N.-Fallon, E. (2009): Strategies to Make Use of Plant Sensors-Based Diagnostic Information for Nitrogen Recommendations. Agronomy Journal. 101. (4), 800.

Szániel, I. - Pálvölgyi, L. - Kertész, Z.-né (1975): Őszi búzafajták egyes minőségi bélyegeinek változásai műtrágyázás és öntözés hatására. Növénytermelés. 24. 219-226.

Zecevic, V.-Knezevic, D.-Boskovic, J.-Micanovic, D.-Dozet, G. (2010): Effect of nitrogen fertilization on winter wheat quality. Cereal Research Communications. 38. 2. 243-249. 
